\title{
Prospects of Soil Organic Carbon Sequestration: Implications for Nepal's Mountain Agriculture
}

- Ngamindra Dabal" and Roshan M. Bajracharya*

* Kathmandu University, Dhulikhel, Nepal

Corresponding author : ngamindra@gmail.com

\begin{abstract}
Agricultural land is one of the major sources of carbon dioxide $\left(\mathrm{CO}_{2}\right)$ emission, which results in an increase of the $\mathrm{CO}_{2}$ concentration in the atmosphere. The conversion of biomass rich land like forests to agricultural land results in the release of carbon into the atmosphere. Once the $\mathrm{CO}_{2}$ enters into the atmosphere, it remains as a potent greenhouse gas for decades unless it is absorbed by plants through photosynthesis. Therefore, there is a need for decades un for abating $\mathrm{CO}_{2}$ enissions by enhancing carbon sequestration. Soils store twice as much carbon than vegetation and two thirds more than the atmosphere, and thus can store a significant quantity of $\mathrm{CO}_{2}$. Unsustainable farming leads to land degradation and the release of soil organic carbon ( $\mathrm{SOC}$ ). SOC may return directly to the atmosphere from the soil when organic material decays through decomposition or burning. SOC is important not only to maintain and enrich soil nutrients, but also in preventing the release of carbon in the forms of $\mathrm{CO}_{2}$ and Methane $\left(\mathrm{CH}_{4}\right)$ into the atmosphere. Mountain agricultural land is sensitive to extreme weather events, such as heavy precipitation or long periods of drought. Such extreme events can trigger high soil erosion leading to losses of SOC. Hence, enhancing and conserving SOC is important for reducing soil erosion and the emission of greenhouse gases from lands, and to maintain a high moisture holding capacity of the soils. In many parts of Nepal, farmers have a topted various soil management practices in an effort to preserve fertile soils, farmers have adopted various soil management practices in an effort to preserve fertile soils,

Key words: climate change, carbon emission, soil, farm manure.
\end{abstract}

\section{INTRODUCTION}

As soil organic carbon (SOC) has an important role in the global carbon cycle, it has generated interest in recent years due to its possible function as a carbon sink. In light of recent concerns over the extent of global warming and the role of SOC as a potential store of atmospheric carbon, there is an increasing pressure and demand to estimate SOC stocks with the greatest possible accuracy (Bell and Worrall 2009). SOC refers to the amount of carbon stored in the soil and is expressed as a weight in percentage and closely related to the amount of soil organic matter (SOM). According to the approximation: SOC x $1.72=$ SOM (Young and Young 2001). There are two ways in which SOC is stored in soil (Bardgett 2005): soil microbial biomass and easily decomposed plant

residues. Carbon is exchanged between the soil and the atmosphere through the process of photosynthesis and decomposition. Plants absorb $\mathrm{CO}_{2}$ and retain carbon while releasing oxygen through the process of photosynthesis. Carbon, which is retained by plants, is then transferred to the soil via roots during the decomposition of plant residues. Subsequently, the carbon is retained in the soil in the form of plant residues which gradually builds into a SOC pool. The carbon stored in the above ground biomass or plant residues is released back to the atmosphere while burning or decomposition and overtime. Thus, there exists a dynamic cycle of sequestration, deposition and transformation of carbon between air and land via plants. 
Conventional agricultural practices, driven by higher production, often fail to replenish the organic inputs in the same proportion they are lost during agricultural production. This leads to a gradual decline of soil fertility. Also, an inadequate supply of organic composts, such as crop residues or cattle manure, results in a reduction of SOC stocks in soils. With some exceptions, the extracted carbon is finally emitted into the atmosphere, making the agriculture lands one of the major sources of carbon emissions. The release of carbon into the atmosphere has dual effects on the environment. Firstly, it decreases the productivity of soils and secondly, it increases the concentration of potent greenhouse gases (GHGs), mainly $\mathrm{CO}_{2}$ and methane $\left(\mathrm{CH}_{4}\right)$, thus accelerating global warming. During the course of conventional farming activities, which involve the use of chemical fertilisers and improvised varieties of crops, SOM and plant decompose, enhancing $\mathrm{CO}_{2}$ emissions. $\mathrm{CO}_{2}$ is the main GHGs released to the atmosphere through multiple sources, like commercial farming practices that use little organic manure and rely heavily on chemical fertilisers (Bajracharya and Atreya 2007). Carbon concentration in the atmosphere increases at the rate of about two parts per million (ppm) per year, primarily from the fossil fuel, biotic and soil pools (Lal 2006).

This paper primarily focuses on SOC and highlights its roles in sustainable agriculture. As SOC is a dynamic constituent in a soil, its change has clear implications for soil properties and agriculture productivity. This study is an attempt to explore the potential of agricultural and forest soils to serve as sinks for atmospheric carbon its potential in crop production, and reduction of GHGs emissions. It is widely perceived that the higher SOC, the better soil quality in terms of its agricultural productivity and moisture holding capacity. In this paper, we analyse literatures on SOC budgets and distributions at global and regional scales as well as factors affecting the stock and flow of SOC in various land use patterns. The regional focus ies primarily on mountain agricultural lands in the Nepali Himalayas. Though the proportion of soil inorganic carbon (SIC) is also substantial in the global carbon budget, we limit our discussions on SOC. The paper first provides an overview on SOC's global budget and its spatial distribution followed by an attempt to relate the SOC context with the stocks of mountain agricultural lands with examples from Nepal. The paper also highlights on the effects of various types of agricultural activities on SOC stocks. Finally, the paper also attempts to derive a message that shows the importance of maintaining rich SOC in agriculture lands and thereby reducing GHG emissions. The paper also highlights policy gaps for rewarding sustainable agricultural practices to the local communities who contribute in preserving SOC.

\section{METHODOLOGY}

The paper is based on desk review. For this purpose analytical review of literatures and key papers on soils and terrestrial carbon cycle primarily published in peer reviewed journals, were made. In addition to this, national and regional seminar and conference proceedings as well as research reports were also reviewed as key sources of information in order to analyse the case of mountain agricultural system of Nepal.

\section{RESULT AND DISCUSSION}

Terrestrial Sources of Soil Organic Carbon

The SOC pool represents a dynamic equilibrium of gains and losses. Of the five principal global carbon pools, the ocean pool is the largest with 38.4 trillion $(\mathrm{mt})$ on the surface layer, followed by the fossil fuels (4.13 trillion $\mathrm{mt}$ ), soils (2.5 
trillion $\mathrm{mt}$ to a depth of one meter), biotic (620 billion $\mathrm{mt}$ ) and atmospheric pools (800 billion $\mathrm{mt}$ ). If the fluxes among terrestrial reserves are combined, annual total carbon flows across the reserves result to an averages around of 60 billion $\mathrm{mt}$, whereas in managed ecosystems (croplands, grazing lands, and plantations) account about 57 percent of the total (Lal 2009).

It is estimated that around 1200 to 1800 gigaton (Gt) of carbon are stored in soils worldwide (Lal 2004a). This is twice of the amount that is stored in all terrestrial plants on the Earth's surface in the form of organic carbon, which is a major source of GHGs, particularly in the form of $\mathrm{CO}_{2}$, and $\mathrm{CH}_{4}$ (Lal 2004a). The soil pool is 3.3 times the size of the atmospheric pool $(760 \mathrm{Gt})$ and 4.5 times the size of the biotic pool $(560 \mathrm{Gt})$ (Lal, 2005). Though there is wide variation in soil carbon estimates, the available data clearly indicates that the total amount of carbon stored in soil is many times higher than the total carbon reserve in the atmosphere.

The loss of carbon from soil pools adversely affects soil quality and subsequently decreases agronomic yields. SOC is a dynamic and essential component of soil in maintaining fertility and other desirable soil properties. Agricultural soil and livestock directly emits large amounts of potent GHGs, namely $\mathrm{CO}_{2}$, $\mathrm{CH}_{4}$ and $\mathrm{N}_{2} \mathrm{O}$. The agriculture sector also produces indirect emissions through fossil fuel use in farm operations or in the production of agrochemicals and the conversion of forests or other types of land use. Considering all direct and indirect emissions, the total global contribution of agriculture sector to GHG emissions is ranges from $8.5-16.5$ pentagrams (Pg) $\mathrm{CO}_{2}$. This represents between $17-32 \%$ of all global human-induced GHG emissions, including land use changes (Bellarby et al. 2008).
The carbon sink capacity of the world' agricultural and degraded soils is 50 to $66 \%$ of the historic carbon loss of 42 to $78 \mathrm{Gt} \mathrm{C}$ ( $\mathrm{Lal}$ 2004a). The rate of SOC sequestration with adoption of recommended technologies depends on soil texture and structure, rainfall, temperature, farming system and soil management. Strategies to increase the soil carbon reserve include soil restoration and woodland regeneration, no-till farming, cover crops, nutrient management, manure and sludge application, improved grazing, water conservation and harvesting, efficient irrigation, agro-forestry practices and growing energy crops on spare lands. The greatest potential for sequestration is in the soil of those regions that have lost the most soil carbon. These are the regions where soil are severely degraded and were used with extractive farming practices for a long time. Most soils have a technical or maximum sink capacity of 20 to $50 \mathrm{mt}$ carbon per hectare that can be sequestered over a 20 to 50 years period. An increase of one ton of soil carbon pool of degraded cropland soil may increase crop yield by 20 to 40 kilograms per hectare $(\mathrm{kg} / \mathrm{ha})$ for wheat, 10 to $20 \mathrm{~kg} / \mathrm{ha}$ for maize and 0.5 to $1 \mathrm{~kg} / \mathrm{ha}$ for cowpeas (Lal 2004b). Carbon sequestration has the potential to offset fossil fuel emissions by 0.4 to $1.2 \mathrm{Gt}$ carbon per year or 5 to $15 \%$ of the global fossilfuel emissions (Lal 2004a).

Conversion of forest to agricultural ecosystems causes depletion of the SOC pool by up to $60 \%$ in soils of temperate regions and $75 \%$ or more in cultivated soils of the tropics. It gets more depleted when the carbon output exceeds carbon input and when soil degradation is severe. For example, some soils have lost as much as 20 to 80 tons carbon per hectare (Lal 2004a). Severe depletion of the SOC pool degrades soil quality, reduces biomass productivity and adversely affects water quality, which may be exacerbated by the projected global warming (Lal 2004a). 


\section{Spatial Distribution of SOC}

A look at the spatial distribution of SOC stocks highlight areas of high carbon storage, that require protection, and areas of low carbon storage with the potential for increase. According to Schlesinger (1982), the distribution of SOC is not globally uniform. Europe is the richest in SOC with $13.7 \mathrm{kgm}^{-1}$ followed by North and Central Asia with $12.4 \mathrm{kgm}^{-1}$ and North America $11.7 \mathrm{kgm}^{-1}$. The average SOC level in South and South East Asia is $8.7 \mathrm{kgm}^{-1}$, which is much lower than the global average of $11.3 \mathrm{kgm}^{-1}$. Levels of SOC stocks in soil are associated with land productivity, soil erosion and water quality (Bajracharya and Sherchan 2009).

Soils store a large share of organic carbon twice more than vegetation and two-thirds more than the atmosphere (Smith 2004). Singh (2007) estimated total stocks of organic carbon in above-ground and below-ground in the three Indian Himalayan states, namely,Jammu Kashmir, Uttarakhand and Himachal Pradesh, to be approximately $700 \mathrm{mt} \mathrm{Cha}^{-1}$, whereas the soil stock in the $69034 \mathrm{~km}^{2}$ alpine meadows of these states is 2.99 billion $\mathrm{mt}$ C. Therefore, soils contribute to a significant quantity to any region's carbon stocks. It is important to understand the roles of any SOC stock in order to quantify the required emission reductions. The difficulty in estimating SOC stocks are revealed by variation in global stock estimates, ranging from 1000 to 3000 Gt (Schwartz and Namri 2002). This is due to huge spatial variability in SOC (Zhi-Yao 2006). Further investigation is therefore needed to establish the measures to calculate the most accurate SOC stocks (Meersmans et al. 2008).

Recognising the importance of SOC dynamics in reducing the rate of atmospheric $\mathrm{CO}_{2}$ increase, the potential to sequester carbon has been studied worldwide. Shi et al. (2009) report that severely eroded soils in China have the greatest potential to sequester carbon $3.72 \mathrm{~T}$ $\mathrm{C})$, while the potential in non-eroded soils is lower $(2.34 \mathrm{Tg} \mathrm{C})$. In general, the potential decreases with an increase in elevation. The highest decrease is areas that lie lower than 300 $\mathrm{m}(5.01 \mathrm{Tg} \mathrm{C})$, whereas areas above $800 \mathrm{~m}$ have only low potentials $(0.25 \mathrm{Tg} \mathrm{C})$. In addition, the type of soil plays an important role in $\mathrm{C}$ sequestration. Red soils have the greatest potential of carbon sequestration (5.32 $\mathrm{Tg} \mathrm{C}$ ) followed by yellowish red soils, brownish red soils and yellow soils. The carbon sequestration potential also varies depending on the parent material sources of the soils. For example, phyllite has the highest sequestration ability (6.81 $\operatorname{Tg} \mathrm{C})$ and the quaternary red has the lowest. Unsustainable farmland management leads to loss of SOC and thereby to a decline in soil productivity. Cropland is one of the major storehouses of SOC, which has been a source of $\mathrm{CO}_{2}$ emissions due to unsustainable land use management and cropping patterns.

In topsoil horizons, where the highest carbon concentrations are found, SOC composition and location has been studied for a long time (Chabbi et al. 2009). Moreover, SOC in subsoil horizons has become the subject of intensive research only in recent years because it was recognised that subsoil carbon contributes greatly to the total carbon stocks within a soil profile (Batjes 1996). Additionally, subsoil is characterised by a radiocarbon age of several hundreds or thousands of years (Paul et al. 1997). High radiocarbon age indicates that stabilised SOC is present in subsoil horizons at important amounts and may therefore serve as a model to study the nature and location of sequestered carbon in soil (Rumpel et al. 2004). The sensitivity of the subsoil carbon pool to climate and land use changes is largely unknown (Don et al. 2007). This is mainly due to the fact that the processes, which led to accumulation of stable SOM in greater soil depth, are yet to be properly understood. Recent research has 
shown that, (1) carbon in subsoil horizons is stabilised by mineral interactions (Eusterhues et al. 2005), (2) its chemical composition is strongly influenced by pedological processes, (3) its stability may be due to the scarcity of fresh plant litter input, which leads to an energy limitation of the soil microbial biomass (Fontaine et al. 2007) and (4) the inability of microbes to physically access the organic matter in deep soil (Xiang et al. 2008). It was recognised that the environmental factors affecting microbial processes in subsoil horizons are distinct compared to those operating in topsoil horizons (Holden and Fierer 2005). Microbial biomass is generally reduced in subsoil horizons compared to those in the topsoil, most probably as a result of decline in the carbon content (Taylor et al. 2002).

Guo and Gifford (2002) have estimated the net gain or loss of SOC occur while converting one form of land use to another. For example, conversion of pastures to plantations amounts for a $10 \%$ loss, from native forests to plantations to a $13 \%$ loss, from native forests to crop fields for a $42 \%$ loss and from pastures to crop fields to a loss of $59 \%$. Further, the studies revealed that a change of forest into pasture brings a gain of $8 \%$, from crop fields to pastures $19 \%$ gain, from crop fields to plantation $18 \%$ gain and from crop fields to secondary forest a gain as much as $53 \%$. The global potential of SOC sequestration through the adoption of conservation tillage with cover crops and crop residue mulch amounted to $0.9+0.3 \mathrm{Pg} \mathrm{Cyr}^{-1}$ with a cumulative potential of soil carbon sequestration as high as 30-60 Pg over 25 to 50 years (Lal 2004a). These assessments contradict the estimates by Schlesinger and Andrews (2000), who argued that large increase in the soil carbon pool seemed unlikely. If other factors remain constant, the potential of SOC sequestration follows a progression of: degraded soil and desertified ecosystems $>$ crop land $>$ grazing lands $>$ forest and permanent crop lands (Lal 2004b).
Soil erosion leads to GHG emissions in four steps - soil breakdown, transport, redistribution and deposition. Globally, erosion induced emission is estimated at $1.1 \mathrm{Pg} \mathrm{C} / \mathrm{y}$ (Lal 2004b). Clearing of native vegetation for agriculture release large quantities of ecosystem carbon as carbon dioxide $\left(5.9 \pm 2.9 \mathrm{Pg} \mathrm{CO}_{2}\right.$-eqyr $\left.{ }^{-1}\right)$ (Bellarby et al. 2008). Thus improvement of soil crop management practices can lead to an increase in concentration of SOC and emission reduction.

Potential for C Sequestration and Emission Reduction Under Improved Agriculture Land Management

Greenhouse gas emissions from land use change have been estimated to account for $20 \%$ of all anthropogenic emissions (IPCC 2007), mostly from forest losses; and the amount is very likely to increase due to additional effects of climate change (Campbell et al. 2009). It is generally agreed that one of the main feedback effects from the climate ecosystems will be through the increase in soil respiration under increased temperature, particularly in the Arctic, with the potential to add $200 \mathrm{ppm} \mathrm{CO}_{2}$ to the atmosphere by 2100 (Canadell et al. 2007). The IPCC assessment (2001) estimated the share of croplands in total global carbon stocks (i.e. 2477 $\mathrm{Gt} \mathrm{C}$ ) to be around $131 \mathrm{Gt} \mathrm{C}$, of which $3 \mathrm{Gt}$ $\mathrm{C}$ is stored in the form of vegetation and 128 Gt $C$ as soil organic carbon. The IPCC estimated that agriculture accounts for $5.16 \mathrm{Gt}$ $\mathrm{CO}_{2}$ e per year in 2005 , which is $10-12 \%$ of the global emissions, mostly through release of $\mathrm{N}_{2} \mathrm{O}$ and $\mathrm{CH}_{4}$. Thus, there is significant potential for emission reductions through agricultural management, mostly through reductions in the loss of SOC. Agriculture is likely to remain a net source (Bell and Worrall 2009), particularly when cropland replaces natural ecosystems, as cultivated soils generally contain 50-75\% less carbon than those in natural ecosystems (Lal 2004b). Enhanced carbon 
sequestration in soil is seen as the most important agricultural mitigation technique in Europe (Bellarby et al. 2008). Changing agricultural land use, in particular through agro-forestry schemes, is one strategy to achieve this. Agro-forestry involves the planting of trees intermingled with crops and increases both standing biomass and soil sequestration and has a high mitigation potential in the tropics (Verchot et al. 2007). Employing no-till agriculture minimises disturbances to soil carbon that can result in high levels of emissions to the atmosphere (Bell and Worrall 2009). Crop genetic diversity rather than monoculture (Lal 2008) also adds to sequester carbon and to prevent soil erosion (Hazzar and Bouassida 2009).

Lal (2009) suggested that increasing carbon pools in the soil beyond a threshold level (about $1.2 \%$ in the surface layer) is essential to enhance soil quality, increase agronomic productivity and improve the quality of natural waters. Furthermore, the author emphasised the strategy of carbon sequestration in soils for cost effectiveness and the safety of biota (vegetative stocks), which has numerous co-benefits over leaving carbon in the atmosphere or sequestering it in the geologic and oceanic strata. Biotic sequestration is based on a natural process whereby $\mathrm{CO}_{2}$ is photosynthesised into organic substances and stored for a long term in plant products and organic soil matter. The natural rate of photosynthesis in the global biosphere is about 120 billion $\mathrm{mt}$ of carbon per year. Fossil fuel combustion emits about 8 billion $\mathrm{mt}$ of carbon annually and deforestation and land-use conversion emit another 1.6 billion to 2 billion mt. A total of 9.6 to 10.8 billion $\mathrm{mt}$ of carbon is emitted per year. Thus, if roughly $8 \%$ of the carbon that is being photosynthesised by the biosphere is retained within the soil and biotic pools, the global carbon budget could be balanced.

Prospect of SOC in Agriculture Lands of Nepal

Being an agricultural country $(66 \%$ of total population), a significant number of mountain farmers in Nepal use farm-yard manure (FYM) as major fertiliser based on their traditional knowledge and technique for generations. This contributed to maintain a balanced input-output ratio of SOC. Traditionally, they rely upon compost or FYM, made of forest litter, crop residues as well as animal manure to replenish croplands. In past generation they used a less intensive and more sustainable fallow farming system, producing only two crops. In recent years, the majority of farmers switched to conventional usage of chemical fertilisers. Over the past two or three decades, however, a shift in cropping patterns spurred on by increasing food and cash-crop demands along with the easy availability of agro-chemicals. This led to diminishing productivity and fertility of arable lands (Bajracharya 2002). Intensified vegetable cropping systems with up to 4 crops grown in the annual cropping cycle become commonplace, especially in peri- and semiurban areas in close proximity to highways and urban markets. The production of major cereal crops was virtually stagnant over the past 15 to 20 years and the national average yields of maize, wheat and rice are well below the attainable and experimental yields. Indeed, the productivity of these crops are well below those reported in neighbouring countries (Kaini 2004). The main reasons for low yields are believed to be the lack of replenishment of soil organic matter and inadequate or inappropriate use of fertilisers (Sherchan and Karki 2005). Since the SOC sequestration leads to improvement in soil quality, increase in agronomy/biomass productivity and improvement in use efficiency of inputs (e.g. fertiliser, water). The beneficial effects for agricultural production of soil 
organic carbon (fresh organic matter, humus) are well known for perennial nutrient sources for plants, increased aggregates stability, increased moisture storage capacity and increased microbial diversity and activity. Higher percentages of SOC generally improve the chemical, physical and biological characteristics of soil.

A development initiative of Sustainable Soil Management Programme (SSMP), a project managed by Helvetas, has been reported to mobilise nearly 100,000 mountain based farming households of Nepal who have adopted locally improved techniques of sustainable soil management and demonstrated that nearly $80 \%$ of the usual demand of chemical fertilisers and pesticides can be reduced through applications of farm yard manure (FYM) techniques along with urine and organic pesticides (SSMP 2009). Moreover, the practices considerably enhance SOC accumulation in cultivated soils by as much as three-fold (Atreya and Bajracharya 2008). SSMP showed that, in a population of 100,000 households in the 15 programme districts with an average land holding of 0.62 hectare, the total amount of SOC stored in the improved FYM land is in the range from 1.77 million tons to 2.90 million tons (Bajracharya and Sherchan 2009). Bajracharya et al. 2004 estimated SOC storage in Nepal's middle hills to be around $423.7 \mathrm{mt}$ C. The authors further revealed that by weight, the spatial distribution of SOC is the lowest in upland between 1 and $2 \%$, while it is between 1.5 and $2.6 \%$ in the lowland. By depth, forest and shrub land have higher amount of SOC $(2.0 \%$ and $2.3 \%$ respectively) than the cultivated soils in the top layer between 1 and $30 \mathrm{~cm}$

FAO's (2006) estimation of organic carbon distributed in above-ground and below-ground biomass, deadwood and litter and soil up to 1 $m$ depth in Nepal's forest and shrub lands is about 1123 million ton. The study showed that the SOC pool holds 496 million metric tons in forest and shrub land. Bajracharya et al. (2006) estimated the total SOC in upland agriculture land of Nepal by extrapolating the sample data of the research plots. With this study, the authors put the final figure of total SOC to be around 37.8 million $\mathrm{mt}$ (CBS 2003). The land area was multiplied by the average carbon density to calculate the total amount of SOC stored in upland agricultural soils of the hills in Nepal.

The SSM techniques include producing farm manure (FM) with crop residues and other biomass, mulching, soil protection (e.g. zero tillage) and crop diversification (multi-cropping) among other practices served to fulfil dual purposes of maintaining soil organic matter in agricultural soils and reducing $\mathrm{CO}_{2}$ emissions from agricultural lands.

\section{Causes of Loss of SOC and Increase $\mathrm{CO}_{2}$ Emission}

Historically, factors such as soil erosion, removal of crop residues, intensive farming and tillage have led to considerable reductions of SOC storage in cultivated and over-grazed soils of Nepal. Sitaula et al. (2004) confirmed SOC loss due to soil erosion which implies that soil erosion control from the farmlands reduces SOC loss and eventual emissions of $\mathrm{CO}_{2}$. Lal (2009) depicts 2 major ways of SOC depletion, namely: (1) the long-term use of extractive farming practices and (2) the conversion of natural ecosystems (such as forest land, prairie lands and steppes) into croplands and grazing lands in Nepal. Such conversions depletes the soil organic carbon pool (reserve) by increasing conversion rate of soil organic matter to $\mathrm{CO}_{2}$, thereby reducing the input of biomass carbon and accentuating losses by erosion. According to (Lal, 2009) most of world's agricultural soils have lost 30 to $40 \mathrm{mt}$ of carbon per hectare over time and their current reserves of soil organic carbon are much lower than their potential capacity. Loss of SOC occurs due to the process of tillage, crop harvesting, excessive 
inputs of chemical fertilisers and soil erosion. Among them, tillage exposes the underlying soil containing organic carbon making it vulnerable to erosion and subsequently releasing $\mathrm{CO}_{2}$ and $\mathrm{CH}_{4}$. Crop harvesting leads to a gradual and permanent removal of SOC from the field unless organic compost is provided. Excessive inputs of chemical fertilisers often accelerate the photosynthesis process of plants leading to depletion of soil nutrients more rapidly than they are naturally replenished. Unsustainable farming (e.g. intensive with high chemical inputs, monoculture and other interventions such as excessive tillage practices) leads to a reduction in SOC and the subsequent release of $\mathrm{CO}_{2}$ into the atmosphere. Conversely, agricultural land may also act as a sink for organic carbon as it can also store and sequester organic matter (mostly from agriculture residues and roots). When adequate amount of organic materials are available in the field during the sequestration process, they are gradually transferred into deeper and more persistent pools of organic deposits, such as within micro-aggregates of the soil or deep within the soil profile. Thus, the land with rich SOC has three beneficial effects: 1) contribute to sequestrate carbon (in deeper layer of soil), 2) enhance productivity (with minimal inputs of chemical fertilisers) and 3) reduce emissions.

\section{Technologies and Practices to Enhance SOC Stock}

Though there is a wide range of low-carbon technologies and innovative practices in use, scientific studies on the dynamics of soil carbon bases and other GHGs in Nepal's agriculture system are inadequate. For example, a project report of the International Centre for Integrated Mountain Development (ICIMOD) enlisted nine different approaches of improved agricultural practices and land management along with fifteen technologies as effective alternatives for improving livelihood of the low-income mountain farmers in Nepal (Providoli et al. 2006). These technologies have not, however, been analysed from the perspective of their effects on carbon sequestration and emission of GHGs.

(Lal, 2004b) reported that the rate of soil carbon sequestration through the adoption of recommended practices (RMPs) on degraded soils range from 100 kilograms per hectare $(\mathrm{kg} /$ ha) per year in warm and dry regions to 1,500 $\mathrm{kg} / \mathrm{ha}$ per year in cool and temperate regions. Further, the study reveals that technical potentials of soil organic carbon sequestration through adoption of RMPs for all cropland soils worldwide ( 1.5 billion hectares) is 0.4 billion to 1.2 billion $\mathrm{mt}$ of carbon per year. Examples of soil and crop management technologies that increase soil carbon sequestration include notill (NT) farming with residue mulch and cover cropping; integrated nutrient management (INM), which balances nutrient application with judicious use of organic manures and inorganic fertilisers; various crop rotations (including agroforestry); use of soil amendments (such as zeolites, biochar or compost); and improved pastures with recommended stocking rates and controlled fire as a rejuvenate method. Further, the author estimates the technical potential of soil carbon sequestration through restoration of degraded/desertified soils (about 2 billion hectares) to be about 0.6 billion to 1 billion $\mathrm{mt}$ of carbon per year and suggests a possible strategy that comprises restoration of degraded/ desertified soils through afforestation and reforestation.

According to Bajracharya and Atreya (2007), significant number of mountain farmers have turned towards reviving the quality of soil for their farmland through adoption of the sustainable soil management techniques. The sustainable soil management (SSM) approach mentioned earlier could be an option for maintaining SOC and enhancing productivity. This, in turn enhances the richness of soil organic 
carbon compared to those under conventional practices. Similarly, Lal (2004b) has recommended various technologies and practices to improve soil quality and efficiency of $\mathrm{C}$ sequestration. If modified and matched to local site-specific conditions and adopted on a broad, regional basis, these practices could contribute significantly to mitigating GHG emissions and, subsequently, reduce effects of the climate change.

Atreya et al. (2006) reported that soil erosion in the mountain farmlands of Nepal led to a loss of $188 \mathrm{Kg} \mathrm{ha}^{-1} \mathrm{y}^{-1}$ of SOC in the farmlands under conventional tillage practice while there was only $126 \mathrm{Kg} \mathrm{ha}^{-1} \mathrm{y}^{-1}$ under non-conventional tillage practice. The study noted that reduced tillage could be a viable strategy to reduce SOC loss, and consequently reduce $\mathrm{CO}_{2}$ emissions as well as saving precious nutrients in the soil.

In some countries, such as Kenya (Bellarby et al. 2008) and Nepal (Atreya et al. 2006), a nominal external support to enhance local capacity to use soil and land management technologies can bring a big change towards improving livelihoods of local farmers and reducing GHG emissions. Thus, enabling the local farmers to adopt SSM techniques helps them to serve a dual purpose of enhancing livelihoods and contributing to emission reduction. It is therefore in the interest of the global climate community to support the initiative in making the global climate funds accessible to the farmers' communities which are willing to adopt SSM techniques. At the national level, Nepal can use the success story of community forestry as a model for smallscale agriculture farming and initiate a comprehensive pilot programme to reduce SOC losses and $\mathrm{CO}_{2}$ emissions while enhancing soil productivity. Nepal can access finances to run such a programme from the existing international climate funds dedicated to leastdeveloped or climate-change- vulnerable countries. The pilot programme will not only provide the broader framework for addressing climate change impacts on agriculture but also build the much needed database of SOC that would pave the way for access to additional funds for the future.

\section{CONCLUSION AND POLICY}

\section{IMPLICATIONS}

Soils serve as both source and sink of $\mathrm{CO}_{2}$. Therefore, they have a great potential to reduce emissions and enhance carbon sequestration through better soil management. In recent years, soil organic carbon (SOC) has received worldwide attention in the context of international policy agendas of $\mathrm{CO}_{2}$ emission. Thus, retaining of SOC is vital not only for maintaining productivity and sustainability of farming systems but also for reducing the rate of $\mathrm{CO}_{2}$ emission. Soils with rich organic carbon levels generally indicate high fertility and therefore it is maintain an optimum level that requires a careful land use and management practices. Recognising the importance of SOC dynamics in alleviating the rate of atmospheric $\mathrm{CO}_{2}$ increase, the potential to sequester carbon has become a topic of deep interest among researchers and policy planners.

Agriculture lands with rich soil organic material have important productivity and resilience benefits. These benefits include improvement in soil quality, increase in use efficiency of inputs, reduction in soil erosion and sedimentation and decrease in $\mathrm{CO}_{2}$ emissions from agriculture land. Food security cannot be achieved without restoring the quality of soils, for which soil carbon sequestration is an essential prerequisite. Soil carbon sequestration can be a win-win strategy to mitigate climate change impacts by offsetting anthropogenic emissions, improving the environment, especially the quality of natural waters, enhancing soil quality, improving agronomic productivity and thereby advancing food security. Without an internationally binding treaty for climate change abatement, it is unlikely 
that an effective national or sub-national policy for emission reduction in the agriculture sector would emerge. The agriculture sector in developing countries offers a huge potential for reducing emissions from soil and enhancing sustainable productivity of the land through SOC enrichment. Climate change threatens agricultural production through higher and more variable temperatures, changes in precipitation patterns and increased number of extreme events such as droughts and floods. Therefore, recognising the roles of the agriculture sector is essential to address the climate change challenges from the sub-national to the international level. In this context, there is a potential of reducing organic soil carbon losses that can be produced into carbon emission reduction credits and traded like any other farm produce. Additional income can be an important incentive for poor farmers in developing countries to invest in soil restoration.

\section{ACKNOWLEDGEMENTS}

The authors would like to acknowledge the financial support provided by Helvetas's Sustainable Soil Management Program (SSMP) particularly by the initiative of Dr. Neeranjan Rajbhandary and Richard Allen. They are thankful to all those reviewers for their comments and valuable suggestions on the paper.

\section{REFERENCES}

Atreya, K. \& Bajracharya, R. M. 2008: Carbon Sequestration in Upland Farming Systems of the Nepal Midhills, Proceedings of National Conference on Environment. Tribhuvan University, Nepal. June 22-24.

Atreya, K., Sharma, S., Bajracharya, R.M. \& Rajbhandary, N.P. 2006. Applications of Reduced Tillage in the Hills of Nepal. Soil and Tillage Research, 88: $16-29$.

Bajracharya, R. M. \& Atreya, K. 2007. Carbon Sequestration in the Upland Farming Systems in the Nepal Midhills. Proceedings of Conference on Emiromment. Tribhuvan University, Nepal. June 22-24.

Bajracharya, R.M. 2002. Fertility and Productivity Parameters for Soil from Five Mid-hill Districts of Central Nepal. Proceedings of International Seminar on
Mountains, (pp 141-150). Kathmandu: Royal Nepal Academy of Science and Technology.

Bajracharya, R.M., Sharma, S., Sitaula, B.K., Dahal, B.M., Rokaya, K. \& Jeng, A. 2006. Assessment of Soil Quality Using Physiochemical and Biological Indicators in Mid-hill Watershed of Nepal. Proceedings of Int'l. Seminar on Environmental and Social Impacts of Agricultural Intensification in Himalayan Watersheds. Oct 15-17, 2006 (pp 105-114). Kathmandu, Nepal.

Bajracharya, R.M. \& Sherchan, D.L. 2009. Fertility Status and Dynamics of Soils in the Nepal Himalaya: A Review and Analysis. In D. P. Lucero\& J. E. Boggs (Eds.), Soil Fertility. Nova Science Publishers.

Bajracharya, R.M., Sitaula, B.K., Shrestha, B.M. Awasthi, K.D., Balla, M.K. \& Singh, B.R. 2004. So Organic Carbon Status and Dynamics in the Central Nepal Middle Mountains. Forestry, 12.

Bardgett, R.D. 2005. The Biology of Soil: A Community and Ecosystem Approach. New York: Oxford University Press.

Batjes, N.H. 1996. Total Carbon and Nitrogen in the Soils of the World. European Journal of Soil Science, 47: 151-163.

Bell, M.J. \& Worrall, F. 2009. Estimating a Region's Soil Organic Carbon Baseline: The Undervalued Role of Land-Management. Elsevier. Geoderma, 152: 74-84.

Bellarby, J., Foereid, B., Hastings, A. \& Smith, P. 2008 Cool Farming: Climate Impacts of Agriculture and Mitigation Potential. Greenpeace International. Amsterdam. (available at www.greenpeace.org retrieved
on Apr.2010) on Apr.2010)

Campbell, A., Kapos, V., Scharlemann, J.P.W., Bubb, P., Chenery, A., Coad, L., Dickson, B., Doswald, N. Khan, M.S.I., Kershaw, F. \& Rashid, M. 2009. Review of Literatures on the Links Between Biodiversity and Climate Change : Impacts, Adaptation and Mitigation. Secretariat of the Convention of Biological Diversity, Montreal. Technical Series No. 42.

Canadell, J.G., Que' re', C. L., Raupach, M. R., Field, C. B., Buitenhuis, E. T., Ciais, P., Conway, T.J., Gillett, N. P., Houghton, R. A. \& Marland, G. 2007. Contribution to Accelerating Atmospheric $\mathrm{CO}_{2}$ Growth from Economic Activity, Carbon Intensity, and Efficiency of Natural Sinks. Proceedings of National Sciences Academy of US A (PNAS) (pp 18866-18870), vol. 104 (, no. 47): 18866-18870.

CBS 2003. National Sample Census of Agriculture, Nepal, 2001/02. Highlights: Central Bureau of Statistics, Nepal.

Chabbi, A., Kögel-Knabner, I. \& Rumpel, C. 2009. Stabilised Carbon in Subsoil Horizons is Located in Spatially Distinct Parts of the Soil Profile. Soil Biology es Biochemistry, 41: 256-261.

Don, A., Schumacher, J., Scherer-Lorenzen, M., Scholten, T. and Schulze, E.-D. 2007. Spatial and Vertical Variation of Soil Carbon at Two Grassland Sites - Implications fo Measuring Soil Carbon Stocks. Godlerma, 141: 272-282. 
Eusterhues, K., Rumpel, C. and Ko" gel-Knabner, I. 2005. Stabilization of Soil Organic Matter Isolated by Oxidative Degradation. Organic Geochemistry, 36: 15671575.

FAO, 2006. Global Forest Resources Assessment 2005. FAO Forestry Paper 147. Rome: Food and Agriculture Organization.

Fontaine, S., Barot, S., Barre' , P., Bdioui, N., Mary, B.\& Rumpel, C. 2007. Stability of Organic Carbon in Deep Soil Layers Controlled by Fresh Carbon Supply. Nature, 450: 277-281.

Freibauer, A., Rounsevell, M.D.A., Smith, P. \& Verhagen, A. 2004. Carbon Sequestration in the Agricultural Soils of Europe. Geoderma, 122: 1-23.

Guo L.B. and Gifford R.M. (2002). Soil carbon stocks and land use change: a meta analysis. Global Change Biology 8 : 345-360.

Hazzar, L. \& Bouassida, M. 2009. A First Version Software Programme for Designing Improved Soils by Vertical Drains. Proceedings of 2nd International Conference on New Developments in Soil Mechanics and Geotechnical Engineering, May 28-30. Cyprus.

Holden, P.A. \& Fierer, N. 2005. Microbial Processes in the Vadose Zone. Vadose Zone Journal, 4: 1-21.

IPCC, 2001. Climate Change 2001: In J. T. Houghton, Y. Ding, D.J. Griggs, M. Noguer, P. J. van der Linden and D. Xiaosu (Eds.). The Scientific Basis, Contribution of Working Group I to the Third Assessment Report of the Intergovernmental Panel on Climate Change (IPCC) (pp944).UK: Cambridge University Press.

IPCC, 2007: Intergovernmental Panel of Climate Change (IPCC) Fourth Assessment Report, Agriculture Working Group III. Chapter 8:,

Kaini, B.R. 2004. Increasing Crops Production in Nepal. In: D.P. Sherchan, K. Adhikari, B.K. Batsa and D. Sharma (Eds.), Proceedings of 24th National Summer Crops Research Workshop on Maize Research and Production in Nepal (pp 15-19). June 28 to 30, 2004, NMRP and NARC, Kathmandu.

Lal, R. 2005. Forest Soils and Carbon Sequestration. Forest Ecology and Management, 220: 242-258.

Lal, R. 2008. Carbon Sequestration. Philosophical Transactions of the Royal Society. Biological Sciences, 363 (1492): 815-830.

Lal, R. 2009. The Potential for Soil Carbon Sequestration. In Agriculture and climate change: An Agenda for negotiation in Copenbagen for Food, Agriculture and the Ewironment. IFPRI Policy Brief 5, pp $16-22$.

Lal, R. 2004a. Soil Carbon Sequestration Impacts on Global Climate Change and Food Security. Science, 304: 16231627.

Lal, R. 2004b. Soil and Forest Degradation in South Asia. Forestry, 12: PP 8-17
Lal, R. 2006. Enhancing Crop Yield in Developing Countries through Restoration of Soil Organic Carbon Pool in Agricultural Lands. Iad Degraldion aud Dorlopmeot 17 : 197-209. Lal, R. 2009. Challenges and Opportunities in Soil Organic Matter Research. European Journal of Soil Science, 60: 158 160.

Meersmans, J. , De Ridder, F., Canters, F., De Baets, S. \& Molle, M. Van. 2008. A Multiple Regressio Approach to Assess the Spatial Distribution of Soll Oranic Can (SOC) at the Regional Scale (Flanders, Belgium). Geoderma, 143 (1-2): 1-13.

Paul, E.A., Follett, R.F., Leavitt, S.W., Halvorson, A., Peterson, G.A. \& Lyon, D.J. 1997. Radiocarbon Dating for Determination of Soil Organic Matter Pool Sizes and Dynamics. Soil Science Society of America Journal, 61 : 1058-1067.

Providoli, I., Bhuchar, S., White, R., Sthapit, K. M. \& Dhakal, M. 2006. People and Resource Dynamics Project (PARDYP) - Participatory Options for Sustainable Sloping Land Management Promoted in Five Sustainable Sloping Land Management Promoted in Five

Rumpel, C., Eusterhues, K. \& Kögel-Knabner, I. 2004. Location and Chemical Composition of Stabilized Organic Carbon in Topsoil and Subsoil Horizons of Two Acid Forest Soils. Soil Biology \& Biochemistry, 36: 177-190.

Schlesinger, W.H. 1982. Carbon Storage in the Caliche of Arid Soils: A case study from Arizona. Soil Science, 133: $247-255$.

Schlesinger, W.H. \& Andrews, J. A. 2000. Soil Respiration and the Global Carbon Cycle. Biogeochemistry, 48 (1): 7-20

Schwartz, D. \& Namri, M. 2002. Mapping the Total Organic Carbon in the Soils of the Congo. Global and Planetary Change, 33 (1-2): 77-93.

Sherchan, D.P. \& Karki, K.B. 2005. Plant Nutrient Management for Improving Crop Productivity in Nepal. Proceedings of Regional Workshop on Improving Plant Nutrient Management for Better Farmer Livelibood, Food Security and Environmental Sustainability (pp 41-57). December 12-16. Beijing, China

Shi, X.Z., Wang, H.Z., Yu, D.S., Weindorf, D.C., Cheng, X. F., Pan, X.Z., \& Chen, J.M. 2009. Potential for Soll Carbon Sequestration of Eroded Areas in Subtropical China. Soil and Tillage Research, 105: 322-327.

Singh, S.P. 2007. Himalayan Forest Ecosystem Services: Incorporating in National Accounting. Central Himalayan Environment Association, Nainital, Uttarakhand, India.

Sitaula, B.K., Bajracharya, R.M. \& Singh, B.R. 2004 Factors Affecting Organic Carbon Dynamics in Soils of Nepal/Himalava Region - A Review and Analysis. Nutrient Cycling in Agro-ecosystems, 70 (2): 215-229. 
Smith, P. 2004. Soils as Carbon Sinks: The Global Context. Soil Use and Management, 20: 212-218.

SSMP 2009. Farmers Profiles from the Mid-hills of Nepal: a Collection of Individual Stories from Partners of the a Collection of Individual Stories from Partners of the Sustainable Soil Management Programme (SSMP).
Document No 151, pp 40. HELVETAS and Inter Document No 151,

Taylor, J.P., Wilson, M.S., Mills, M.S. \& Burns, R.G. 2002. Comparison of Microbial Numbers and Enzymatic Activities in Surface Soils and Subsoils Using Various Techniques. Soil Biology \& Biochemistry, 34: 387-401.
Xiang, S.R., Doyle, A., Holden, P.A. \& Schimel, J.P. 2008. Drying and Rewetting Effects on $\mathrm{C}$ and $\mathrm{N}$ Mineralization and Microbial Activity in Surface and Subsurface California Grassland Soils. Soil Biology \& Biochemistry, 40: 2281-2289.

Young A \& Young, R. 2001 Soils in the Austalian Landscape. Oxford University Press, Melbourne.

Zhi-Yao, S., Yong-Mei, X., Jian-Yun, Z., Yong-Chang, Y \& Mai, Y. 2006. Soil Organic Carbon Content and Distribution in a Small Landscape of Dongguan, South 